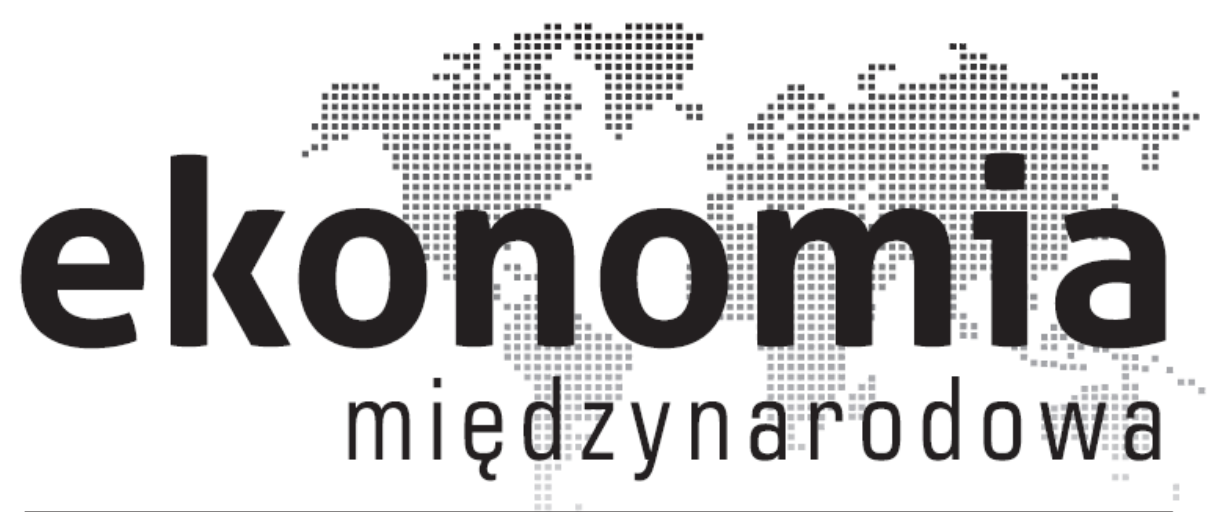

Ekonomia Międzynarodowa

Nr 14 (2016)

Wydawca: Uniwersytet Łódzki

(Publisher: University of Lodz)

www.ekonomia-m.pl

ISSN: 2082-4440 - wydanie papierowe (paper edition)

ISSN: 2300-6005 - wydanie elektroniczne (electronic edition)

Wersja elektroniczna czasopisma jest wersją referencyjną

(Electronic edition is the reference version of the journal)
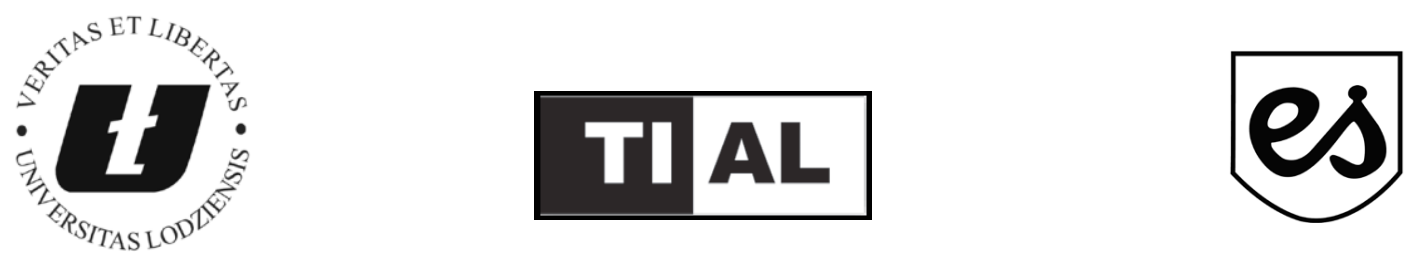


\section{Impact of Innovative Financial Products on Financial Systems: Exchange Traded Products and the Polish Financial System}

Adam Marszk*

\section{Introduction}

Over the last few decades the range of instruments offered by financial institutions has increased significantly. Examples of such instruments include Asset Backed Securities, Collateralized Debt Obligations, which played a key role in the global financial crisis of 2008, as well as Exchange Traded Funds, part of the broader category of Exchange Traded Products. Exchange Traded Products and Exchange Traded Funds are currently among the most rapidly developing financial instruments and have become increasingly popular in many regions.

Development of the Exchange Traded Product (ETP) and Exchange Trade Fund (ETF) markets has a significant impact not only on the participants of transactions involving the purchase or sale of ETP/ETF units but also for the entire financial systems, leading to new threats and opportunities that need to be assessed by, for example, local regulatory authorities. Such evaluations are complicated by the multiple links between instruments listed and traded in different countries; some such interdependencies are described in this text.

The main objective of this text is to present the key trends in the global and Polish ETP market and assess possible threats to the Polish financial system. Analysis of the main indicators will be performed using selected descriptive statistics in a dataset compiled from multiple sources, some of them neglected in previous research.

The first section of the text will include an overview of the main types of ETPs, the key mechanisms of their creation and trading, the most important benefits, and the changes occurring on the largest segment of the ETP market - the ETF market. Of special interest in the ETF market is the development of 'synthe-

\footnotetext{
*Adam Marszk - PhD, Gdańsk University of Technology, Faculty of Management and Economics, Department of Economic Sciences.
} 
tic' ETFs, which lead to many risks, some of which are not yet fully recognized by market participants and supervisors. An overview of these risks will be presented based on selected literature. The second section will present the structure and developing trends in the global ETP market, mostly in terms of assets under management. The third section will concentrate on the Polish financial system: ETFs available in Poland and, what is one of the main novelties of this study, ETFs listed outside Poland that offer returns based on Polish assets and which are intimately related to the Polish market.

The topic of the ETF market in Poland has been discussed by a few authors (e.g. Chodnicka and Jaworski 2012; Mitrenga 2014; Miziołek 2013; Nawrot 2007; Płókarz 2012). Some of them focused on possible benefits and disadvantages of ETFs for investors by comparing them with other instruments, or checking their return and risk profile, while others concentrated on the history and structure of the Polish ETF market. To the best of the author's knowledge, there have been no studies on possible risks to the Polish financial system stemming from the development of the ETF market. Moreover, in the overviews of the Polish ETF market, instruments listed abroad with exposure to Polish assets were ignored, due to the difficulty of accessing the appropriate data. Such omissions may lead us to question the conclusions of those papers, because the size of such assets is much bigger than of ETFs listed and traded in Poland. In this study, this issue is addressed.

\section{Exchange Traded Products: main categories, advantages and disadvantages}

Exchange Traded Products (ETPs) form a wide group of financial products ${ }^{1}$ that are traded on exchanges (International Organization of Securities Commissions 2013, p. 1): Exchange Traded Funds (ETFs), Exchange Traded Commodities (ETCs), Exchange Traded Notes (ETNs), and Exchange Traded Vehicles (ETVs). It should be noted that ETFs are the oldest type of such products, the rest of them having been introduced in the last ten years, and the largest type in terms of assets under management. In May 2015 they constituted about $95 \%$ of the assets of all ETPs (ETFGI 2015, p. 3). Consequently, ETFs will be presented in more detail than the other types of ETPs. Opportunities and threats of ETPs will be discussed using the example of ETFs.

\section{Exchange Traded Funds: mechanisms, categories}

ETFs are funds that are traded on exchanges in a manner similar to stocks and allow investors to gain exposure to several asset classes, usually stock market

\footnotetext{
${ }^{2}$ In this text terms 'financial product' and 'financial instrument' will be used interchangeably.
} 
indexes, on a real-time basis (International Monetary Fund 2011, p. 68). Gaining exposure means, in this context, acquiring an instrument with prices changing in line with prices of selected financial assets. In other words, the instrument is tracking the performance of selected assets. Contrary to conventional products, such as mutual funds, which may also have similar features, the units of ETFs can be traded intra-daily ${ }^{2}$. The first ETFs were introduced in North America in the late 1980s and early 1990s (Deville 2006, pp. 4-6). In Asia, ETFs were introduced on the Hong Kong exchange in 1999, and in Europe they were launched in 2000 (Deville 2006, p. 6; Marszk 2014). Soon after their introduction, ETFs became popular among various groups of investors: institutional investors such as pensions or hedge funds - for strategic and tactical purposes or to circumvent restrictions concerning investing in derivatives - and retail investors (Aggarwal and Schofield 2014, pp. 80-84).

There are currently many types of ETFs available to investors; they can be categorized according to the offered exposure. The most popular type are equity ETFs, which offer exposure to the equity market, usually to broad market indexes, such as developed, emerging, or global equity market ETFs, orto indexes of stocks in selected sectors such as the banking industry (called sector equity ETFs), or to groupings of companies of a chosen size (capitalization equity ETFs). Less common are strategy, style, or thematic equity ETFs (Deutsche Bank 2015, pp. 76-81). Other basic types of ETFs are fixed income ETFs, linked to a money market, corporate or government debt, and commodity ETFs, usually tracking indexes of precious metals - for example, gold ETFs are very popular in India (Aggarwal and Schofield 2014, pp. 82-88).

The development of the ETF market and growing interest in such instruments led to the creation of even more advanced types of ETFs. A key innovation in this market was the introduction of 'synthetic' ETFs, so labeled in order to distinguish them from the usual ETF linked to 'physical' funds. Synthetic ETS are based on derivative instruments. This distinction currently seems to be the most significant one and deeply shapes the opportunities and threats of ETFs for investors and financial systems. The risks of synthetic ETFs will be presented with reference to the basic mechanisms of ETF creation, distribution, and trading.

Physical ETFs are established by financial institutions (referred to as the ETF providers) which buy and physically hold all securities constituting the tracked index or, in some cases, their representative sample (Dickson et al. 2013, pp. 4-5). On the basis of this basket of securities, units of an ETF are issued; next, they are distributed by authorized participants and sold to institutional or retail investors (Ramaswamy 2011, pp. 2-4). ETF units (or, to be more precise, ETF shares) are listed on selected stock exchanges and can be bought or sold in the same manner as other

\footnotetext{
${ }^{2}$ Mutual funds are Investment companies that buy a portfolio of securities and manage them according to a specified financial goal, ready to buy back their shares at a price calculated by the company (Investment Company Institute 2015, p. 277).
} 
listed securities, by using brokerage services. The prices of the shares of an ETF are kept close to the prices of the tracked assets by arbitrage transactions, allowed to a large extent by sophisticated trading systems (Lechman and Marszk 2015).

Shares of synthetic ETFs are also listed and traded through exchanges. However, the underlying tracking mechanism is very different and more complicated. Instead of purchasing and holding a basket of securities, the institution managing such a fund enters into a derivative contract, usually a total return swap (IOSCO 2013, p. 2). The counterparty of the contract delivers the total return on the tracked assets (e.g., a stock market index) and the ETF provider pays the agreed funding rate (Foucher and Gray 2014, pp. 40-41).The ETF provider gains the interest necessary to pay the funding rate by investing in collateral using the funds from the sale of ETF units. The structure of such an ETF is called 'synthetic funded' as opposed to the slightly different 'synthetic unfunded' structure in which the ETF provider buys a substitute basket of securities and exchanges its return for the returns of the tracked assets also in a swap contract (Naumenko and Chystiakova 2015, p. 26). The ETF provider does not buy tracked assets in either of the synthetic structures.

The types of ETFs haveover the past few years become even more diverse. The division of ETFs according to their various exposures is currently insufficient for classifying them. Increasingly complicated types of ETFs have recently been created. Some examples are leveraged ETFs (offering performance of selected assets multiplied by a certain factor), inverse ETFs (tracking opposite performance), leveraged-inverse ETFs (combination of the two just mentioned), actively managed ETFs (tracking a group of assets not constituting an index), and, launched most recently, currency hedged ETFs and enhanced beta ETFs, which offer investment strategies based on modified currency or index exposure (Deutsche Bank 2015, p. 15; Financial Stability Board 2011, pp. 3-5).The complexity of these ETF categories is one of the factors hindering the evaluation of their possible impact on a micro or macro scale. Another separate, but related, topic is the creation of options on ETFs, which have become very popular especially in the USA - their turnover now exceeds all US stock options (Ramaswamy 2011, p. 8).

\section{Exchange Traded Funds: opportunities and threats}

Opportunities and threats stemming from the use of ETFs may be discussed at two levels: micro and macro, here understood as the consequences for participants in the ETF market (micro) and the consequences for the entire financial system in which ETFs are traded or in which they have an influence in other ways as discussed later (macro).

The macro level is particularly important in the context of this paper. The discussion in this section will be based on various publications; it should be stressed, though, that the macro implications of the growing popularity of ETFs had 
been ignored until the first reports published in 2010. However, researchers still tend to focus on the micro effects of ETF usage, and the lack of studies on macro implications constitutes a significant research gap, particularly with reference to countries such as Poland.

ETFs may be regarded as innovative financial instruments, offering benefits for their users that are unavailable for users of traditional instruments. The basic benefits of ETFs, the underlying cause of their popularity, result from the comparison of their characteristics with those of similar conventional instruments such as mutual funds. The main advantages of ETFs in comparison with mutual funds are, among others, the following features (Agapova 2011; IMF 2011 pp. 68-69;Ramaswamy 2011, pp. 1-4):

1. lower costs (mostly only costs of exchange transactions);

2. lower tracking errors (i.e., deviations of return on ETF from return on tracked assets) due to arbitrage transactions - particularly low for synthetic ETFs;

3. higher liquidity, more efficient pricing mechanisms, and easier application for offsetting other exposure due to listing and trading through exchanges (prices of ETF shares are updated continuously during trading hours, whereas the valuation of mutual funds is determined usually only once a day);

4. greater tax efficiency - in some countries.

Other advantages (Lechman and Marszk 2015) are the following:

1. low initial investment barrier that makes ETFs affordable even for investors with limited funds;

2. ability to access assets easily in other (even geographically distant) countries by purchasing ETFs with foreign exposure;

3. ability to diversify the investor's portfolio easily.

Even though the benefits (for particular investors, that is, on a micro scale) discussed above refer to both physical and synthetic ETFs, the two types of funds differ in some more specific aspects (Kosev and Williams 2011, pp. 54-55). The relative advantages of physical ETFs are greater transparency, a higher level of investor security (there is a great chance of receiving one's capital in the case of the fund being liquidated), and compliance with regulations in many countries which forbid the use of derivatives in such instruments. On the other hand, the advantages of synthetic ETFs are lower costs, better access to some asset classes (for example, illiquid ones), and lower tracking errors.

Apart from the above-mentioned threats, investing in synthetic ETFs exposes the buyer to a risk not present in physical ETFs - counterparty risk. Counterparty risk can be defined as a risk of the default of the counterparty in the swap contract entered into by the ETF provider and the failure to provide the promised return on tracked assets (Ramaswamy 2011, pp. 4-8). Other related types of counterparty risk are linked with the poor quality of collateral (e.g., low liquidity), interest rate 
risk (return on collateral insufficient to cover the funding costs of the swap) or opaque transaction within financial groups when both sides of the swap agreement have the same owner (resulting in conflicts of interest). However, the results of research in this field show that counterparty risk may be lower than previously estimated (Hurlin et al. 2014). Moreover, counterparty risk can be limited, as in Europe, by regulations on ETFs (Dickson et al. 2013, pp. 10-11).

Another risk carried by ETFs, not only to investors but also to the entire financial system (at both micro and macro levels), is liquidity risk (Kosev and Williams 2011, pp. 55-56). The liquidity of ETF shares is strongly linked with the liquidity of the tracked assets (a decrease in liquidity of, for instance, tracked stocks can lead to a fall in the liquidity of corresponding ETF shares). Moreover, some ETF markets remain rather shallow; thus one or a few large transactions may cause an increased disparity between prices of the ETF shares and prices of the tracked assets. On a larger scale, ETFs may increase the market volatility large, sudden changes in prices inthe stock market(or other tracked market) will lead to similar changes in the ETF market. Such a feedback loop will amplify the initial shock - an example is the 'Flash Crash' of 2010 in the US stock market. Yet another similar risk factor is related to the possible disruptions in the ETF arbitrage mechanisms - keeping the tracking error low - resulting from the regulatory constraints applied to ETF providers (Foucher and Gray 2014, pp. 42-44). It may lead to a prolonged period of significant deviations of ETF prices from the underlying instrument's prices and, consequently, to an investor run ending in a breakdown of the ETF market. Taking into account the size of the ETF market, such a breakdown would probably spill over to the market for the underlying instrument and to other ETFs.

Furthermore, commodity ETFs have been mentioned as one of the reasons for the increased volatility of the commodities markets (Diaz-Rainey and Ibikunle 2012; Rubino 2011, p. 31). This problem is assessed as being not serious with reference to ETFs on gold or other precious metals, which are currently used mostly as investments. However, growing interest in ETFs led to the development of ETFs that track prices of basic commodities such as food and energy. The ETFs then led to increased speculation on these commodities markets. As a result, commodity ETFs are accused of moving productive assets from the real economy to the financial sector and contributing to growing inflation.

Risks carried by ETFs to the financial systems are magnified by their cross-listings on more than one exchange, usually in many countries (Lechman and Marszk 2015). Multiple listing poses a risk of shock transmissions between various exchanges, even those very distant from each other. The risk of contagion may also be attributed to ETFs traded in one country and offering exposure to assets listed in other countries. Such ETFs are not supervised by authorities in the country whose assets they track while they have strong links to its financial markets and may influence them through the ETFs' creation and trading processes. This 
problem may be exacerbated by regulatory differences. For example, a synthetic ETF based on assets in a given country might be listed on a foreign exchange due to a ban on synthetic ETFs in the country of the underlying asset.

Finally, supervisory authorities need accurate and timely information on financial instruments such as ETFs in order to perform their functions. As mentioned above, ETFs, especially synthetic ones, are complicated instruments, created and traded by many market participants, sometimes located in different countries. The complexity and the geographical distance can lead to low transparency and insufficient disclosure, both of which impede the evaluation of their current and potential risks for financial stability. Therefore, despite the growing importance of ETFs, their impact on the financial systems is difficult to assess.

\section{Other categories of Exchange Traded Products}

Apart from ETFs, investors can use other types of ETPs. The most notable group is Exchange Traded Notes (ETNs) - debt instruments traded on exchanges, offering exposure to selected stock or bond market indexes (Dickson et al. 2013, p. 7). In contrast to ETFs (which are equity instruments), these products are debt securities. It means that, in addition to risks typical of ETFs, buyers of ETNs must also face the credit risk of the issuer (IOSCO 2013, p. 43). The next category, Exchange Traded Commodities (ETCs), is similar to ETNs, but they offer exposure to the commodities market, usually by employing derivatives such as futures or forwards (Kosev and Williams 2011, pp. 53-54; Ramaswamy 2011, p. 7). Finally, Exchange Traded Vehicles (ETVs) are products similar to ETFs and ETCs but are in the legal form of grantor trusts (not funds or debt securities) and are available only in the USA (Deutsche Bank 2015, p. 100). Nevertheless, it should be noted that all categories of ETPs other than ETFs, despite high growth rates, are still of minimal significance to the financial system.

\section{Global ETP markets: main trends}

This section will be devoted to an overview of the main global ETP market development trends and will focus on the following aspects: the product type and the listing region. Within the several types of products, the structure of the ETF market will be presented separately because ETFs constitute the largest ETP category. The changes in the market share of synthetic ETFs will be presented using the example of European markets. Analysis in this and the subsequent section will be conducted using the author's customized, personally gathered and processed dataset on ETPs (ETFs) prepared by combining data from international financial institutions, stock exchanges, and regulatory authorities as well as information gathered from reports published by ETF providers (Black Rock 2012; Deutsche 
Bank 2014, 2015; ETFGI 2015; ICI 2015; Warsaw Stock Exchange 2015; World Federation of Exchanges 2015).The results presented in this section concerning Poland should be regarded as preliminary due to insufficient data; this part of the database, part of a research project initiated in 2015, is still under construction.

Shortly after their introduction on various markets, ETPs (initially only in the form of ETFs) gained popularity among investors as evidenced by the growing value of Assets Under Management (AUM). The period of their fast growth began in the early 2000s, that is, after the launch of the first ETFs in Europe and Asia. In 2001 (all data are year-end or month-end), there were 221 ETPs in the world, including 209 ETFs and 12 other ETPs. The vast majority of ETPs were listed in the USA (about $50 \%$ in terms of number of products; about $80 \%$ in terms of AUM). The second most important market was Asia (mostly Japan), and the third was Europe. Only a few ETPs were listed in other regions. The global AUM of ETPs amounted to about 110 billion USD. Over the following years, the assets of ETPs grew significantly in all regions-the AUM of all ETPs listed worldwide in May 2015 slightly exceeded 3 trillion USD, a record-high value (see Figure 1). During the 2001-2014 period, the AUM of ETPs decreased only once on a yearly basis, in 2008. That decrease was linked to factors affecting the entire global economy and financial system (for example, the financial crisis and public and private debt issues in the euro-zone).After initial growth in the share of other ETPs (ETNs, ETCs, and ETVs) in total AUM of the ETPs (with the highest share occurring in 2010 and 2011 at about $11 \%$ ), in the next few years ETFs regained their popularity. According to the newest data available, the share of other ETPs started on a downward trend in 2012 and decreased to less than $5 \%$; the causes of the decreases are similar to the ones observed on the synthetic ETFs market, described in this section.

Figure 1. Assets under management of all Exchange Traded Products listed in the world, including Exchange Traded Funds and other products (in bln USD), 2001 - May 2015

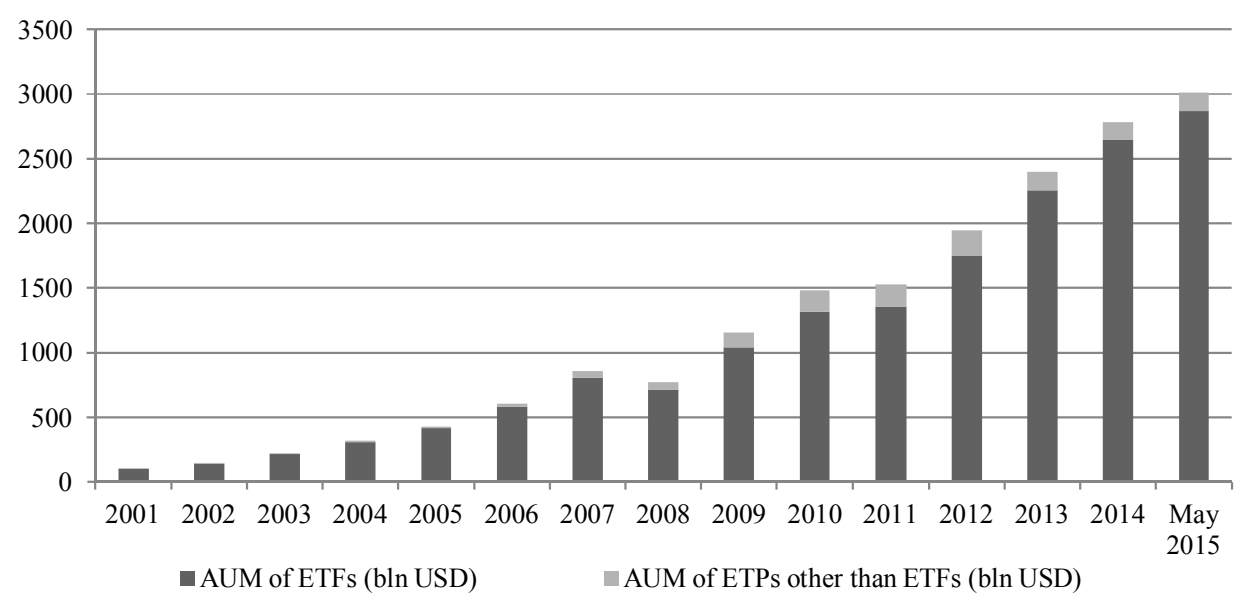

Source: own elaboration based on ETFGI 2015, p. 3. 
Figure 2 displays the geographical structure of the global ETP market, divided into four key regions (USA, Europe, Asia Pacific, and Japan) and the rest of the world. Note that the combined share of the rest of the world is comparable to one single market - Japan. The geographical distribution of ETPs has not changed significantly since 2001; the US market is still the largest in terms of AUM. Nevertheless, its share in total global AUM of ETPs declined to about $70 \%$ in 2008 and remains at this level. The share of ETPs listed in Europe grew from about $6 \%$ to $17 \%$; at some point, in 2009 and 2010, it even exceeded 20\%. The European ETP market is thus now the second largest; and the Japanese market, whose share until 2004 was similar to the European share, is now smaller than the US, European, and Asian Pacific markets. The Asian Pacific market consists mostly of ETFs listed in mainland China, Hong Kong, South Korea, and India. Dynamic growth of the ETP market in Europe until 2010 was spurred by the development of synthetic ETFs.

Figure 2. Assets under management of all globally listed Exchange Traded Products by region (in bln USD), 2001 - May 2015

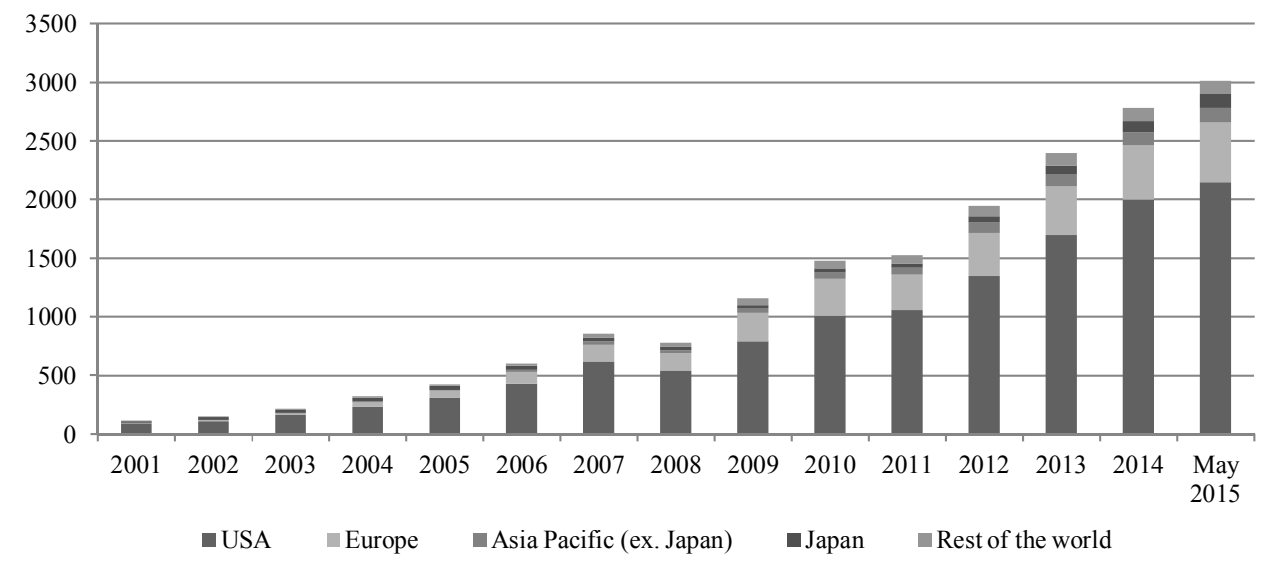

Source: own elaboration based on (Deutsche Bank 2015, p. 76-81; ETFGI 2015, p. 3-9).

As evidenced by Figure 1, ETFs constitute the majority of the global ETP market. It should be remembered, though, that they are not a homogenous group of instruments - ETFs offer exposure to various asset classes and are structured in various ways (see the discussion on types of ETFs in the previous section). Despite the product innovations, most current ETFs remain similar to the first such products - instruments tracking the performance of selected stock market indexes. Such instruments are the largest group of ETFs in terms of AUM; they belong to the equity class presented in Figure 3. The trend observed over the last few years is one of the decreasing popularity of emerging market ETF safter the boom ended in 2012, and the increasing popularity of developed market ETFs and 
of capitalization equity ETFs regardless of the country. The second biggest group is fixed income ETFs, usually tracking corporate bond market indexes; somewhat less often they are based on sovereign bond market.

Figure 3. Asset class structure of the global Exchange Traded Funds market in 2014

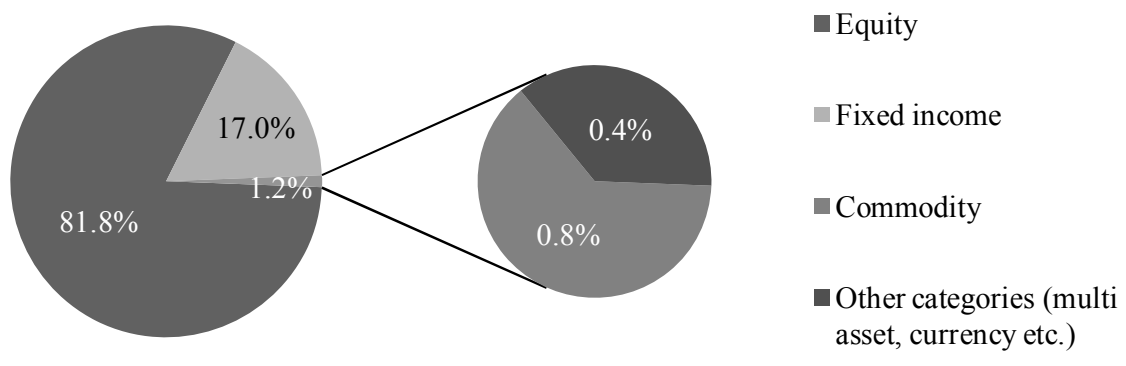

Source: own elaboration based on (Deutsche Bank 2014, p. 68-73; 2015, p. 76-81; ETFGI 2015, p. 3-9).

Figure 4. European ETF market structure (in terms of AUM) by type of replication, 2006-2013

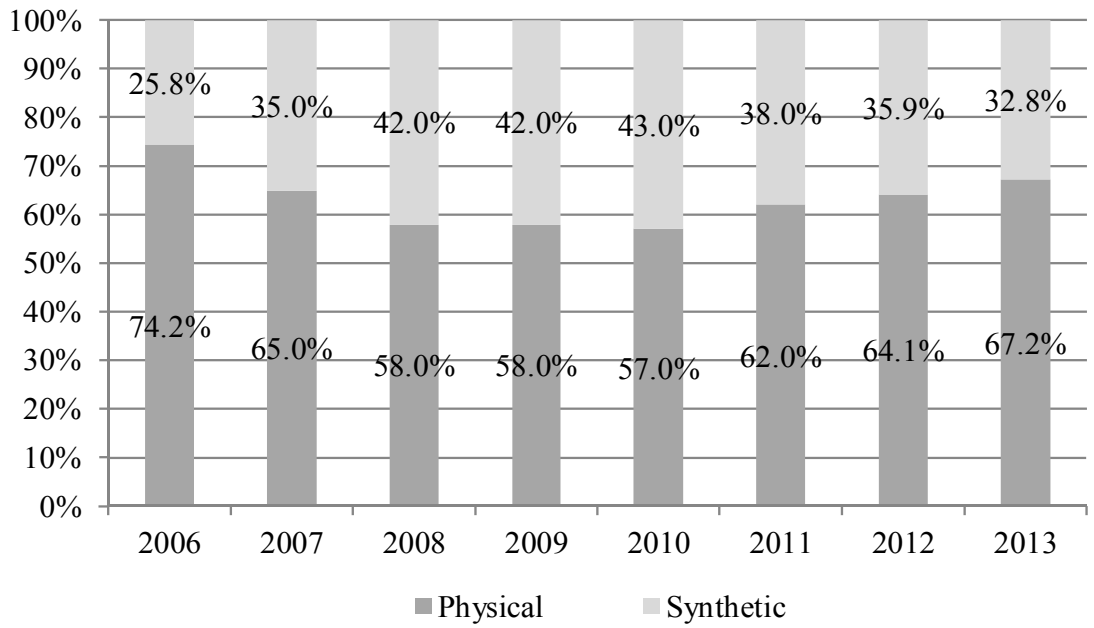

Source: own elaboration based on (Deutsche Bank 2014, p. 15; ETFGI 2014, p. 11).

Synthetic ETFs are listed and traded almost solely in Europe; there are a few recent exceptions in Asia, especially South Korea. The rise of synthetic ETFs in Europe was caused by regulationst hat allowed the creation and distribution of funds based on derivatives. The advantages of synthetic ETFs (e.g. lower costs and tracking errors) attracted the attention of many market participants and were key factors in their success. The assets of synthetic ETFs grew rapidly between 2006 and 2010, when their market share reached an all-time record value of $43 \%$ (see Figure 4). However, over the next few years the popularity of synthetic ETFs in Europe diminished. One of the key 
causes was a growing awareness among ETF buyers of threat linkages between ETFs and synthetic ETFs. Until 2010 ETFs were, to a large extent, ignored by supervising authorities as they were regarded as rather safe products which played a minor role in European and global financial markets. Due to sharp increases in the assets of synthetic ETFs, especially in 2009 and 2010, their potential risks came under close scrutiny of many institutions, including the Bank for International Settlements (Ramaswamy 2011). Decreasing demand for synthetic products made ETF providers switch to physical, more transparent replication schemes, or at least improve disclosure standards on synthetic ETFs (Hurlin et al. 2014, p. 27). Apart from micro risk reduction for investors, this change had positive macro consequences for the level of potential risk for the entire financial system, especially for Europe, the central trading place for synthetic ETFs. Moreover, providers of synthetic ETFs in the European Union need to follow stricter guidelines introduced by the European Securities and Markets Authority (European Securities and Markets Authority 2012).

\section{ETPs and the Polish financial system}

Analysis of the Polish ETP market will cover only ETFs, because they are currently the major group of such products that are listed in Poland or that track Polish assets $^{3}$. This section is divided into three parts. The first part will concentrate on the ETFs listed in Poland on the Warsaw Stock Exchange (WSE). The second part will discuss ETFs tracking Polish financial assets listed abroad. The third part will provide a short overview of the risks posed by ETFs to the Polish financial system.

\section{ETFs listed on the Warsaw Stock Exchange}

Unsuccessful attempts to introduce ETFs on the Polish exchange can be traced back to 2002. The first successful attempt occurred in 2010 when an ETF was launched on the WSE, many years after similar listings on the most developed financial markets (Chodnicka and Jaworski 2012, p. 199). There are currently three ETFs listed on the WSE, all of them managed by Lyxor Asset Management. These ETFs track the following indexes: the Polish WIG20 (the first ETF listed in Poland, available solely on the WSE), the US S\&P 500 (listed primarily on Deutsche Boerse but cross-listed in Poland and Italy) and the German DAX (also listed primarily in Germany and cross-listed in a few countries). The AUM of ETFs listed on the WSE amounted at the end of 2014 to 787.87 million USD, a lower value than in the previous three years (see Figure 5). The highest value was reached in 2013 when it exceeded 1.2 billion USD. It should be taken into account that most of these values comprised

\footnotetext{
${ }^{3}$ Other instruments listed on the Warsaw Stock Exchange and labeled sometimes as 'Exchange Traded Products' are not included in the ETP universe by leading providers of ETP data such as Black Rock, Deutsche Bank or ETFGI as they do not have the required features.
} 
assets of ETFs listed primarily outside Poland. The AUM of the only entirely 'Polish' ETF (that is, tracking a Polish index, listed solely on the WSE) was about 80 million USD, similar to the first year of its listing in 2010.

Figure 5. Assets under management of all Exchange Traded Funds listed in Poland (in mln USD), 2010-2014

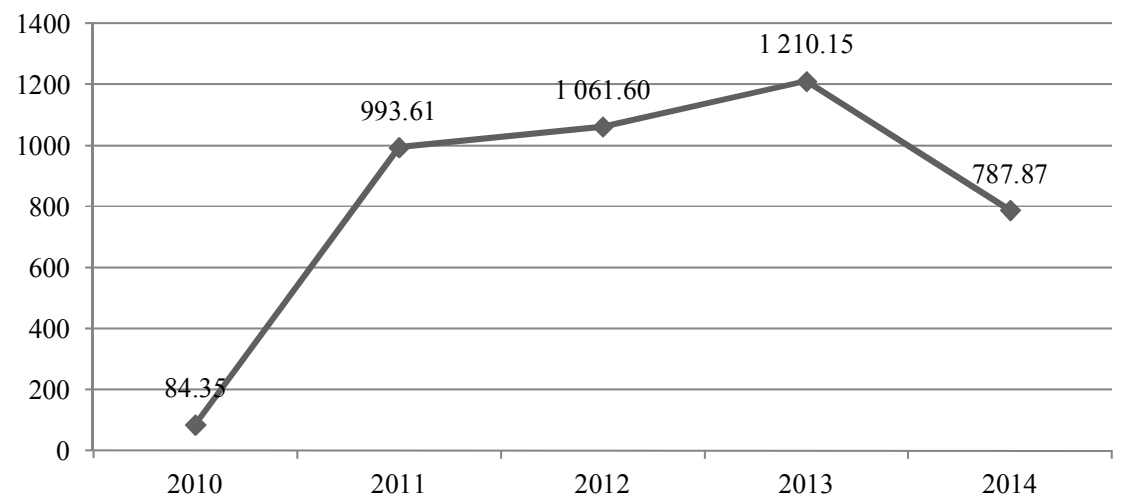

Source: own elaboration based on WSE 2015.

Trends in the annual turnover of ETF stocks on the WSE are presented in Figure 6. After a sharp increase in the value of traded stocks in 2011, over the next years it gradually declined, down to 29.1 million USD in 2014. Comparing values of turnover with the AUM of ETFs listed in Poland shows that they remain illiquid instruments: turnover constitutes only a few percent of AUM. It also indicates that values of AUMs are inflated by internationally-listed ETFs - even though they are listed on the Polish exchange and contribute to the total AUM, they are traded mostly on other exchanges.

Figure 6. Annual turnover of Exchange Traded Funds' shares on the Warsaw Stock Exchange (in mln USD), 2010-2014

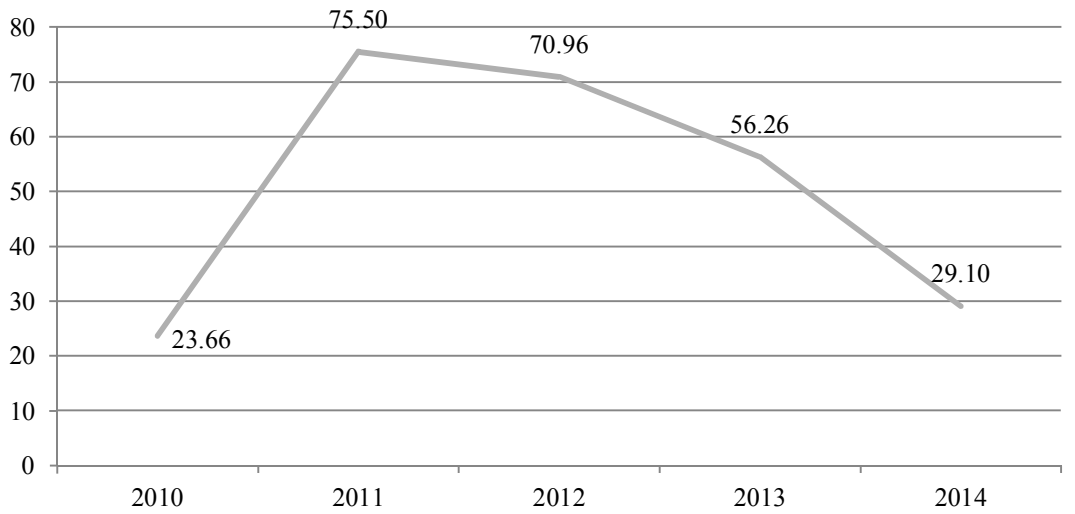

Source: own elaboration based on WFE 2015; WSE 2015. 
The ETF tracking the WIG20 index remains the most liquid despite its relatively low value of assets compared to the two other ETFs listed in Poland. According to trading data for the July 2014 - June 2015 period (displayed in Figure 7), the ETF based on the WIG20 constituted the vast majority (about 62\%) of the total ETF turnover. Underdevelopment of the Polish ETF market is also indicated by comparison of the AUM of ETF with the AUM of conventional investment products, that is, mutual funds. Using 2014 year-end data on the AUM of these two categories, the calculated share of ETFs (only primary listings in order to avoid double counting) in total Polish investment funds, the sum of ETFs and mutual funds (Lechman and Marszk 2015) exceeded 0.3\% (ICI 2015, p. 237; WSE 2015). For comparison, on leading ETF markets, the typical share of ETFs was between $4 \%$ and $10 \%$.

Figure 7. Shares of tracked indexes in turnover of Exchange Traded Funds' units on the Warsaw Stock Exchange between July 2014 and June 2015

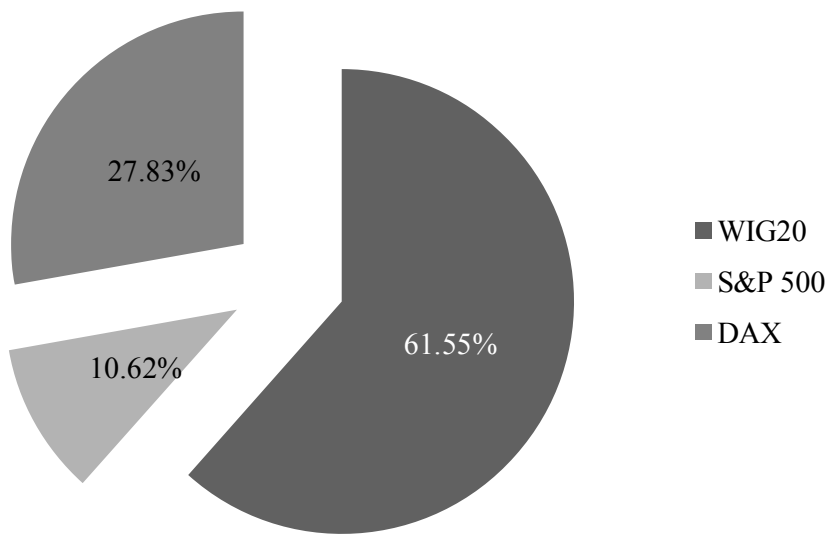

Source: own elaboration based on WSE 2015.

\section{ETFs listed abroad, tracking Polish assets}

There has been no previous research on ETFs tracking Polish assets, mostly due to the lack of such data in reports published by international institutions observing the ETF market. The value of ETFs tracking Polish assets, already listed abroad, is very difficult to estimate due to the large number of such instruments and the lack of comprehensive lists. The author created a customized database by analyzing financial reports of several ETFs listed worldwide and calculating the value of managed Polish assets. Figure 8 displays selected results of that process - the value of Polish assets in the portfolios of ETFs listed outside Poland grouped by region 
and asset class ${ }^{4}$. The AUM of such funds was estimated at about 1 billion USD; for comparison, the AUM of the WIG20 ETF listed in Poland was about 80 million USD. This large difference in AUM shows why ETFs listed abroad cannot be ignored in the evaluation of the possible risks for the Polish financial system.

Figure 8. Assets under management of Exchange Traded Funds tracking Polish assets listed outside Poland (in mln USD), end of June 2015

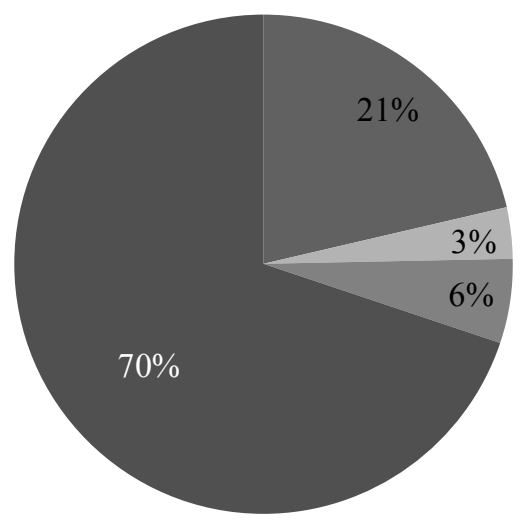

- USA: single country equity

- USA: emerging markets or sector equity

Europe: equity

Fixed income

Source: own elaboration based on reports published by fund provider, and databases on websites: www.etfdb.com, www.etftrends.com. Note: only Polish assets were used for calculations.

The largest category of ETFs listed on the European and US exchanges, with links to the Polish financial markets, are fixed income ETFs (listed mostly in the USA). At the end of June 2015, they managed Polish bonds worth more than 750 million USD, issued mostly by the Polish state (sovereign bonds). The second largest category was ETFs listed in the USA and tracking only Polish stock market indexes; the AUM of one such fund, iShares MSCI Poland Capped, was almost three times higher than the AUM of the WIG20 ETF listed in Poland. Other ETFs that invest in Polish stocks are emerging markets or sector ETFs listed in the US and European equity ETFs. Polish assets can be found, for example, in US ETFs managing stocks of companies in the metal industry. The European equity category is rather small, probably due to the fact that European investors can easily access Polish assets on the integrated financial markets in the EU, whereas for the American category it is more problematic. It should also be mentioned that US ETFs with exposure to Polish assets are often cross-listed. Therefore, they are

\footnotetext{
${ }^{4}$ It should be underlined that values presented in Figure 8 are slightly underestimated - there are thousands of ETFs worldwide with Polish assets in their portfolios. For the calculations, only ETFs with at least $1 \%$ of their assets invested in Poland were taken into account. The database is still being expanded (the next step will involve the addition of more ETFs listed in Europe) and will be used in the future for continued research on selected ETFs including, inter alia, econometric modeling of the ETF's market development trajectories, identification of factors influencing market development, impact on the financial systems, and projections concerning future changes.
} 
listed and traded not only in the USA but also in a few cases in countries such as Mexico and Japan.

Based on the selected indicators of the ETF market in Poland discussed in the preceding paragraphs, it should be stated that the market remains underdeveloped. The leading ETF in terms of turnover is based on the Polish stock market index and listed in only one country. Two other ETFs, listed primarily on other exchanges, may be viewed as possible sources of shock transmission; it should be remembered, however, that they account for a minority of ETF turnover on the WSE. Another possible risk factor is the method of replication used by ETFs listed in Poland. The ETF tracking the WIG20 delivers returns using a synthetic structure through swap agreements. According to the overview presented in the theoretical section, such instruments can lead to a number of threats for their users and the financial systems. Nevertheless, by both the value of the AUM and the turnover, this ETF plays a minimal role in the Polish financial sector.

\section{Risks to the Polish financial system}

The second part of the analysis was devoted to ETFs listed outside Poland that track Polish assets. Their AUM is much higher than that of ETFs listed in Poland (with two cross-listed funds excluded). Most are listed in the USA and use physical replication schemes. The share of synthetic ETFs is minimal; even European equity ETFs with Polish exposure usually have a physical structure. This small share means that synthetic ETFs do not constitute a large risk for the Polish financial system. Nonetheless, such funds pose a few types of risk for the financial sector which cannot be ignored. The first of them is related to where they are listed. As most of them are listed outside the EU, regulatory control over them by Polish financial supervisory authorities is difficult or even impossible. Such lack of supervision may be dangerous, especially in times of financial distress. Current and potential risks of ETFs for the financial system may differ from the Polish perspective and from the listing-country perspective. Secondly, ETFs listed abroad may lead to the transmission of shocks involving declines in prices, liquidity, or both; particularly dangerous is a contagion from the ETF markets to the underlying markets. In this case it would most probably mean a fall in prices of Polish bonds as well as increased volatility due to transactions linked with foreign ETF markets. This type of risk becomes more serious due to the dynamic growth in ETF assets and the scale of cross-listing. Even though the AUM of fixed income ETFs with Polish exposure is still low compared to the size of the Polish bond market, such disruptions can occur with regard to some bond issues. Finally, even though there are almost no such ETFs linked with Polish assets, Poland is also exposed to the risks posed by the commodity ETFs such as increased prices of basic commodities and magnified volatility in this market. 


\section{Conclusions}

The situation in the ETP market is very dynamic - new types of products are constantly launched on the markets and well-known instruments often undergo deep transformation. The introduction of synthetic ETF structures drastically changed the risk profile of the linked financial instruments. There are, however, some features typical of this kind of financial product that caused their high - and still growing - popularity among the investing audience. The most important benefits, using the example of the leading category (ETFs), are the following: low costs, low tracking errors, high liquidity, access to continuously updated prices, ease of investing, and many applications. Investing in such products is linked with a number of risks for market participants; depending on the type of the instrument chosen they include counterparty, transparency, and liquidity risks. Development of the ETP market may also have some negative consequences for the entire financial system: magnified liquidity downturns or price volatility, the risk of shock transmission, problems with correct risk evaluation by supervisory authorities, and speculation in commodities markets.

The Polish situation is quite unusual if compared to developed financial markets, as the highest risk comes from ETFs listed abroad which track Polish assets, not from ETFs listed in Poland. The key risk factors that should be taken into account are the threat of shock transmission in, for example, the bond market, and the lack of adequate regulatory oversight from the point of view of the Polish financial system. Listing on foreign exchanges and cross-listing impedes oversight and hinders reacting to possible threats. The analysis presented in this paper is a starting point for further evaluation, which will be conducted based on extended datasets in order to assess more fully the impact of ETPs on the Polish financial system.

\section{References}

Agapova A. (2011), Conventional mutual index funds versus exchange-traded funds, Journal of Financial Markets, 14(2).

Aggarwal R., Schofield L. (2014), The Growth of Global ETFs and Regulatory Challenges [in]: Kose J., Makhija A.K., Ferris S.P. (eds.), Advances in Financial Economics, Emerald Group Publishing Limited.

Black Rock (2012), ETP Landscape - Global Handbook 2012.

Chodnicka P., Jaworski P. (2012), Śledząc parkiet - analiza jakości odwzorowania indeksu WIG20 przez pierwszy na polskim rynku fundusz Exchange Traded Fund, Problemy Zarzadzania, 39(4).

Deutsche Bank (2014), ETF Annual Review \& Outlook 2014.

Deutsche Bank (2015), ETF Annual Review \& Outlook 2015. 
Deville L. (2008), Exchange Traded Funds: History, Trading and Research [in:] DoumposM., Pardalos P., Zopounidis C. (eds.), Handbook of Financial Engineering, Springer US.

Diaz-Rainey I., Ibikunle G. (2012), A Taxonomy of the 'Dark Side' of Financial Innovation: The Cases of High Frequency Trading and Exchange Traded Funds, International Journal of Entrepreneurship and Innovation Management, 16(1).

Dickson J., Mance L., Rowley Jr. J. (2013), Understanding synthetic ETFs. Vanguard Research, June 2013.

ETFGI (2014), ETFs Revisited.

ETFGI (2015), ETFGI Monthly Newsletter May 2015.

European Securities and Markets Authority (2012), Guidelines for competent authorities and UCITS management companies: Guidelines on ETFs and other UCITS issues.

Financial Stability Board (2011), Potential financial stability issues arising from recent trends in Exchange-Traded Funds (ETFs).

Foucher I., Gray K. (2014), Exchange-Traded Funds: Evolution of Benefits, Vulnerabilities and Risks, Bank of Canada Financial System Review, December 2014.

Hurlin C., Iseli G., Perignon C., Yeung S. (2014), The Collateral Risk of ETFs, Université de Genève Working Paper Series.

International Organization of Securities Commissions (2013), Principles for the Regulation of Exchange Traded Funds.

International Monetary Fund (2011), Global Financial Stability Report: Durable Financial Stability. Getting There from Here, World Economic and Financial Surveys.

Investment Company Institute (2015), Investment Company Fact Book 2015, Washington, DC.

Kosev M., Williams T. (2011), Exchange-traded Funds, Reserve Bank of Australia Bulletin, March Quarter.

Lechman E., Marszk A. (2015), ICT technologies and financial innovations: the case of Exchange Traded Funds in Brazil, Japan, Mexico, South Korea and the United States, Technological Forecasting and Social Change, 99.

Marszk A. (2014), Exchange Traded Funds (ETFs) on emerging markets [in:] BuszkoM., Huterska A., Piotrowski D. (Eds.), Perspective: Challenges of modern finance and banking, Nicolaus Copernicus University in Torun Publishing, Torun.

Mitrenga D. (2014), Oszacowanie błędu naśladowania przez dostępny na polskim rynku fundusz ETF wraz z określeniem jego przyczyn, Studia Ekonomiczne Uniwersytetu Ekonomicznego w Katowicach, 177.

Miziołek T. (2013), Pasywne zarzadzanie portfelem inwestycyjnym - indeksowe fundusze inwestycyjne i fundusze ETF, Wydawnictwo Uniwersytetu Łódzkiego, Łódź. 
Naumenko K., Chystiakova O. (2015), An Empirical Study on the Differences between Synthetic and Physical ETFs, International Journal of Economics and Finance, 7(3).

Nawrot W. (2007), Exchange-Traded Funds: Nowe produkty na rynku funduszy inwestycyjnych, Cedewu Wydawnictwa Fachowe, Warszawa.

Ramaswamy S. (2011), Market structures and systematic risks of exchange-traded funds, BIS Working Papers No. 343, Basel.

Rubino J. (2011), Emerging Threat Funds?, CFA Magazine, 22(5).

Warsaw Stock Exchange (2015), WSE Fact Book 2014.

World Federation of Exchanges (2015), WFE Database.

\section{Summary}

Exchange Traded Products (ETPs) are one of the most recent and most rapidly developing financial products. As their assets grow they have an increasing impact on financial systems in many countries, including the USA, UK or Japan. Development of ETPs is linked with many opportunities and threats for the local financial systems. Their correct assessment is becoming more difficult due to the growing complexity of the available products, thus posing problems not only for the participants of the financial markets (including buyers and sellers of ETPs as well as intermediaries) but also for the supervising authorities. The main ETP development trends (e.g. size of the global assets under management) are outlined in this article. Structural changes are discussed in the context of their impact on both local and global financial systems. One of the key topics is the consequences of the changing landscape of the most popular type of ETP - Exchange Traded Funds (ETFs). Simple and safe physical ETFs are being replaced by complicated synthetic ETFs, significantly increasing possible risks for the holders of such products, for other entities involved in their creation and distribution, and, consequently, for the whole financial system. The last part of the article is devoted to the Polish perspective on this topic. It may be argued that in Poland the role of ETPs (even ETFs) is still marginal. ETPs can influence the Polish financial system, however, through a number of links between Polish and foreign financial institutions and markets. As a result, fast transmission of the future shocks caused by such products is increasingly more probable.

Keywords: Exchange Traded Funds, financial innovations, financial stability, mutual funds 


\section{Streszczenie}

Wpływ innowacyjnych produktów finansowych na systemy finansowe: przykład Exchange Traded Funds (perspektywa globalna i polska)

Exchange Traded Products (ETPs) są jednymi z najnowszych i najszybciej rozwijających się produktów finansowych. Wraz ze wzrostem wartości aktywów rośnie także ich wpływ na systemy finansowe wielu krajów, m.in. USA, Wielkiej Brytanii oraz Japonii. Rozwój ETPs niesie ze sobą wiele szans i zagrożeń dla lokalnych systemów finansowych. Prawidłowa ocena tego oddziaływania staje się coraz trudniejsza z powodu coraz większego stopnia skomplikowania dostępnych produktów. Przekłada się to na problemy nie tylko uczestników rynków finansowych (w tym nabywców i sprzedawców ETPs oraz pośredniczących w transakcjach), ale również instytucji nadzorczych. W artykule zostały omówione główne trendy na rynkach ETPs. Prezentowane zmiany przedstawiono w kontekście ich wpływu na systemy finansowe w skali lokalnej i globalnej. Jednym z głównych omówionych zagadnień są konsekwencje zmian w ofercie najpopularniejszych ETPs, tj. Exchange Traded Funds (ETFs). Proste i bezpieczne fizyczne ETFs są obecnie wypierane przez znacznie bardziej skomplikowane produkty syntetyczne, co znacząco zwiększa poziom zagrożenia dla posiadaczy tego typu produktów, innych podmiotów zaangażowanych $\mathrm{w}$ ich tworzenie i dystrybucję, a w konsekwencji dla całego systemu finansowego. Ostatnia część została poświęcona omówieniu problemu w odniesieniu do polskiego systemu finansowego. Choć rola ETPs (nawet ETFs) jest w Polsce niewielka, to mogą one oddziaływać na polski system finansowy przez szereg powiązań pomiędzy polskimi a zagranicznymi instytucjami finansowymi i rynkami. Oznacza to zagrożenie przeniesienia do Polski potencjalnych przyszłych szoków wywołanych tymi produktami.

Słowa kluczowe: Exchange Traded Funds, innowacje finansowe, stabilność finansowa, fundusze inwestycyjne

JEL: G10, G23, G24

Praca powstała w wyniku realizacji projektu badawczego o nr 2015/19/D/HS4/00399 finansowanego ze środków Narodowego Centrum Nauki

This article is a result of scientific project no. 2015/19/D/HS4/00399 financed by the National Science Centre of Poland 